\title{
Introduction:
}

\section{Marc Angenot and the Scandal of History}

It's fashionable to suggest that the social sciences and the humanities are undergoing a "crisis," or that the new millennium, the New World Order, or some other grand force has led us, or should lead us, to reevaluate our presuppositions about the work undertaken in the domains of which they are composed. Even a brief glimpse into the literary, historical, and cultural theories of past eras suggests that, in fact, each moment of history was rife with tensions and discord that threatened to challenge in fundamental ways prevailing dogmas of a given culture or a particular discipline. It's perhaps more fruitful to suggest that the present moment, like moments that preceded it, is dominated by a series of assumptions, questions, and approaches tied to a finite set of theories, and associated with a small number of theorists who for some reason not necessarily related to quality or importance have risen to the top of an exceptionally rich mixture of work undertaken inside of, and beyond, the academy. The goal of this issue on Marc Angenot is to give the mixture a shake, to call up from its vast multiplicity of writings a corpus of work which, on account of its ambition, its depth, and its implications, deserves a more prominent place in the fields of criticism, history, and language studies, for a range of reasons.

Consistent with other leading foreign-born figures who have risen to prominence in the realms of theory and criticism in the United States, including Eric Auerbach, Mikhail Bakhtin, Roland Barthes, Jacques Derrida, Paul de Man, Edward Said, Ferdinand de Saussure, and René Wellek, Marc Angenot had a classical and rigorous education, in his case in philosophy, rhetoric, literature, and, crucially, philology, which, along with his great erudition and original approach to language studies, history, and literature, should put him in the company of those who are most cited on the critical scene. And yet his work is far less known than the corpuses of Barthes, Baudrillard, Deleuze, Guattari, Kristeva, Lacan, or even Lyotard, in part because he is not connected to either the U.S. scene or to the oddly closed and closely knit Parisian realm from which so much post-New Criticism work has emerged. Even Foucault, whom he references regularly in his discussions of discourse analysis, is but a point of departure, as he says in his assessment of French postmodern theory:

The Yale Journal of Criticism, volume I7, number 2 (2004): I63-182

(C) 2004 by Yale University and The Johns Hopkins University Press 
The only name which also belongs to the canonical American list of French theorists is that of Michel Foucault, which I will talk about, but only to show that influence does not necessarily entail adherence. Contact with the work of Foucault has taught me a lot, but almost always a contrario, as I admired his conjectures and progress but, in the end, I rejected most of his premises, approaches and conclusions. Furthermore, in thinking about Foucault, I confronted his ideas with those of Koyré, Bachelard, Kantorowitz, Popper, Kuhn and other less brilliantly nihilistic epistemologists, and compared his history of nineteenth-century sexuality with that of Peter Gay for instance, who contradicts him in all regards. This may sound like rather deceitful praise, but it is sincere, and this is the way it often happens in the evolution and spread of ideas. Saying this at the outset in no way underestimates Michel Foucault's innovative talent-nor his obvious faults. ${ }^{1}$

Darko Suvin makes a similar point in his contribution to this volume when he notes that "Marc Angenot's adjectival addition of 'social' to the Foucault-inspired discourse is not innocent: it is correlative to the outstanding fact that Angenot is philologically one of the most solid eruditions I've met-incomparably more so than Foucault. Each of Marc's works is impregnated by a not only admirably extensive \& ambitious but also (diametrically opposed to the brilliant slapdash improvisations of Foucault, not to speak of his imitators) a precisely delimited \& magisterially understood sociohistorical corpus."2 Within these observations dwell the issues I'll address in this introduction, notably, the sources of Angenot's approach, the value of his work for historical and contemporary debates, and the nature of a man who is by his work and his life a dear and ever-present interlocutor.

\section{Early Milieus}

Marc Angenot's father, Marcel Angenot (1879-1962), was an accomplished intellectual and writer and eventual curator of the Camille Lemonnier Museum in Ixelles, Belgium. At the age of sixty years he met thirty-year-old Zoé Marthe De Clercq, with whom he had his first and only child two years later, on December 2I, I94I, in Uccle. The family lived modestly in different areas of Brussels, with Marcel's income subsidized by Zoé's work as a milliner. Marc was educated entirely in Belgium, beginning with work in Humanités gréco-latines (I958), a candidature in Philosophie et Lettres (I96I), a Licence in Philosophie et Lettres ("Expansion et condensation dans Stèles de Victor Segalen," I963), and, finally, a Ph.D. in Philosophie et Lettres (philologie romane) at the Université libre de Bruxelles, for which he wrote a I,609 page thesis called "Rhétorique du surréalisme," defended in 1968. Part of the requirements for the degree were two shorter tasks, which Angenot fulfilled with his annexes called "La promotion du Créole haïtien comme langue de culture" and "La Complainte de Fantômas de Robert Desnos, parodie de la Complainte de Fualdès." The seeds of Angenot's approach were sown in this period, 
partly through his wide-ranging readings in philosophy, philology, formalism, and also in his studies of rhetoric, reflected in the thesis title and inspired in part by the great Chaïm Perelman. He was also deeply influenced by Lucien Goldmann, who in those years was affiliated with Brussels Institut de sociologie and La revue de sociologie. The principal language for his work was and remains French, although, consistent with his comparatist and interdisciplinary approach, he works as well in English, Flemish, Spanish, Italian, German, Latin, and ancient Greek.

Angenot's teaching began in a secondary school in Brussels $(1963-4)$. He moved on to a research position with the Fonds national [belge] de la recherche scientifique (1964-7, Université libre de Bruxelles) and then, in 1967, he began to look for a full-time university position. There were three postings in his department, one in Zaire, one in Algeria, and one in Canada, and although well-equipped for any of them, he decided to take the offer from the French Department of McGill University, Montréal. Québec in the I960s was living the effects of its "quiet revolution," which involved a political and cultural awakening from long years of Maurice Duplessis isolationism and Roman Catholic conservatism. McGill, an anomaly on the Québec scene, was looking to establish a graduate program in literature for which it necessarily turned outside of Canada's borders since, particularly in French Canada, graduate education in the humanities was restricted to only a few disciplines, and advanced degrees in French literature or comparative literature were all but unknown. Angenot has been in Montréal ever since, adding to his duties in the French Department by being one of several adjunct faculty in the Comparative Literature Program at McGill from 1978 until its premature demise in I99I. Over the years, Angenot has taught courses on science fiction, the narrative, rhetoric, narratology, intertextuality, social discourse, discourse analysis, socialist propaganda, argumentation, sociology of literature, grand narratives, sociocriticism, and "le mal social," approaches to social ills. Along the way he has directed 27 theses (M.A. and Ph.D.) on related subjects including Gaston Bachelard, science fiction in France, the French Revolution as portrayed in novels, "A Thousand and One Nights," modernism, fascist aesthetics, the image of Latin American revolutionaries in France, semiotics, rhetorics, discourses and narratives of hysteria, Proust, Veblen, and Tarzan, to name but a few. He has taught as well at Concordia University, Université du Québec, the Universidad Nacional de Rosario (Argentina), Universidade Federal do Rio Grande do Sul, Porto Alegre (Brazil), Universidad Nacional de Córdoba, and the University of Toronto, and he has given hundreds of talks around the world.

Angenot has also been instrumental in starting a series of institutes, centers, and movements which, little known in the U.S., have never- 
theless played important roles in professional circles concerned with comparative literature, science fiction, discourse analysis, and the history of the left in France. In 1968, he started the Inter-University Center in Para-Literature, advancing a key theme in his intellectual development that would lead in 1975 to the publication of his first book, Le roman populaire: recherches en paralittérature. ${ }^{3}$ From the perspective of this study, paraliterature was not to be denigrated, or assessed via the "canon" of literature, just as "literature" should not be placed upon the pedestal of intellectual endeavors, to be studied with gloved hand and hushed voice. For Angenot, the regrettable effect of isolating and idolizing certain authors and texts is to miss out on whole realms of modern social discourse, just as methods for analyzing them proliferate within and beyond the academy. This tension, between "literary" and language studies, between canonized texts and those apparently not worthy of careful scrutiny, was too great to bear, and led Angenot to move increasingly to studies of the broader "social discourse" and to one of his early great texts, La Parole pamphletaire: contribution à la typologie des discours modernes. ${ }^{4}$ This assessment of "littérature de combat" examines polemical texts published in the form of pamphlets and satires (in French) in the modern period, from I868-I968, assembling a typological and rhetorical analysis and proposing along the way a synthesis of the social roles played by the pamphlet, work which in retrospect paved the way for later studies of the broad range of social discourses present in particular social settings.

\section{Marketplaces of Discursive Practice}

Angenot's interest in discursive formations led him in I98I to found le Cercle québécois d'étude des formations discursives, rechristened in I984 as the Montréal Inter-University Circle for the Study of Social Discourse. In 198I, Angenot also joined André Belleau's Bakhtin Circle, and the two scholars, united on a host of ideas and interests, grew to be close friends. The influence Bakhtin had upon Angenot's writings is tangible, not only through this period, which ended with the premature death of Belleau in I986, but right through to the present moment. The "social" of Angenot's social discourse means that language practice cannot be isolated from other discursive practices, not only in related texts, as suggested by the idea of intertextuality, but in the entire ambient cacophony of voices. This suggests that to understand Angenot, one must be versed in a host of theories that have assessed the relationship between Saussure's "langue" and "parole" or, in more social terms, word and context, or utterance and hegemony. Angenot invites such comparisons early on in his essay about social discourse, stating that it "is based on a number of ideas and notions coming from different horizons, and the reader will recognize a num- 
ber of intellectual debts I owe to Antonio Gramsci, Mikhail Bakhtin, Raymond Williams, and Michel Foucault as well as to thinkers somewhat less known to English-speaking audiences such as the Argentinian-born semiotician Luis Prieto, the novelist, philosopher, and historian of Fascism, Jean-Pierre Faye, the most prominent French figure in cultural sociology today, Pierre Bourdieu .... and many others." 5

In my opinion, Bakhtin's and Bourdieu's writings are particularly useful places to start for an understanding of Angenot's work because they set out the basis of his own reflections on the relationship between an utterance and the discursive world into which it is spoken. For Angenot, as for Bakhtin before him, "we are taking language not as a system of abstract grammatical categories, but rather language conceived as ideologically saturated, language as a world view, even as a concrete opinion, insuring a maximum of mutual understanding in all spheres of ideological life. Thus a unitary language gives expression to forces working toward concrete verbal and ideological unification and centralization, which develop in vital connection with the processes of sociopolitical and cultural centralization." 6 The word and the utterance are "saturated" in ideology, but are also bathing in a very particular time at which an utterance occurs, which calls up not only the conditions of the speaking subject but indeed every element of the context within which, and to which, the word is spoken. This leads Angenot to a crucial preliminary point in his thinking about "social discourse," which is that "at any moment and in spite of different ideologies in competition, there exists a diffuse thematic paradigm that may undergo innumerable avatars but nevertheless provides the basic features of a dominant world-view. Such a thematic paradigm is not necessarily embodied in a specific philosophy or doctrine of the time; it may be more elusive, existing both everywhere and nowhere. Fashionable ideologies of the moment provide successive versions or variants of [it]." This idea of discursive "fashions" is present as well in Bakhtin's work, in which it is strongly tied to the stratification of language into different speech genres that gain and lose value depending upon the chronotope within which they are uttered:

The internal stratification of any single national language into social dialects, characteristic group behavior, professional jargons, generic languages, languages of generations and age groups, tendentious languages, languages of the authorities, of various circles and of passing fashions, languages that serve the specific sociopolitical purposes of the day, even of the hour (each day has its own slogan, its own vocabulary, its own emphases) - this internal stratification present in every language at any given moment of its historical existence is the indispensable prerequisite. ${ }^{8}$

Consistent with this idea, Angenot suggests that any attempt at studying discourse must be clearly inscribed within a broader project of understanding the broader "social discourse," which demands of the reader or listener a clear understanding of the historical circumstances 
as well as the prevailing norms of emission and reception, in order to accord the discursive commodities the speaker is attempting to peddle on the open market. This brings us back to Bakhtin, who theorizes this relationship in his suggestion that "the word, directed toward its object, enters a dialogically agitated and tension-filled environment of alien words, value judgments and accents, weaves in and out of complex interrelationships, merges with some, recoils from others, intersects with yet a third group: and all this may crucially shape discourse, may leave a trace in all its semantic layers, may complicate its expression and influence its entire stylistic profile."

If discursive exchanges do in fact occur this way, then the speaker of this "word" must be familiar with the local fashions, what is "stylish" from a discursive standpoint and what isn't. Bakhtin explains this orientation by suggesting that "the word in living conversation is directly, blatantly, oriented toward a future answer-word. It provokes an answer, anticipates it and structures itself in the answer's direction. Forming itself in an atmosphere of the already spoken, the word is at the same time determined by that which has not yet been said but which is needed and in fact anticipated by the answering word. Such is the situation in any living dialogue." 10 Angenot's contribution to this approach is his description of this social discourse "environment," helping us to understand why one "atmosphere" might prevail over another. Whereas Bakhtin often describes this relationship in vitalistic terms, as though the utterance is organic and takes on a life of its own, Angenot is more material-minded in his "social discourse" approach and therefore much more apt to think of the utterance as commodity than as living being:

This division of discursive labor may also be approached in the logic of market and commodities. Discourses circulate, their value is regulated by supply and demand, they are marketed and exchanged. All discursive topologies are subject to a specific economy with its market engineering, supply and demand, planned obsolescence of ideological goods, inventories, and clearance sales. A whole new economy with its fashions, infatuations, inflations, and crashes, conflicts with the preservation principle and the need to control the limits and outskirts of the thinkable. Hence the frequency of that classical compromise: the "foreseeable newness," or the art of making new out of old. ${ }^{11}$

This idea, key to his work on how utterances circulate in a social discourse, moves Angenot away from Bakhtin and toward Bourdieu's description of linguistic exchange as economic transaction between a "producer, endowed with a certain linguistic capital, and a consumer (or a market), and which is capable of procuring a certain material or symbolic profit."12 From Bourdieu's perspective, utterances aren't "signs to be understood and deciphered; they are also signs of wealth, intended to be evaluated and appreciated, and signs of authority, intended to be believed and obeyed," which leads him to the very sad 
but salubrious observation that "quite apart from the literary (and especially poetic) uses of language, it is rare in everyday life for language to function as a pure instrument of communication. The pursuit of maximum informative efficiency is only exceptionally the exclusive goal of linguistic production and the distinctly instrumental use of language which it implies generally clashes with the often unconscious pursuit of symbolic profit."13 Angenot, in his article "What Can Literature Do?", isn't even willing to provide the caveat of "literary uses of language" in his own work, a crucial difference between him and sociocritics like Régine Robin or Darko Suvin.

\section{The Limits of the Sayable}

To establish symbolic profit, the speaker counts on, and attempts to establish, some basis for the communication of his or her value, credibility, or viability. But the process is highly complicated because, according to Angenot's approach in "Social Discourse," the underlying rules of the social discourse "comprise a thematic repertory, an implicit cognitive system (or perhaps several cognitive systems in competition), and a regulated topology, a division of labor in the discursive realm. These are the basic components of what engenders the sayable, the writable, institutionalized discourses of all kinds, the discursive acceptability at a given historical moment in a given society." 14 Herein we find echoes of Bakhtin's idea that the story being told exists inside of a series of "complex interrelationships, consonances and dissonances," so any kind of understanding that occurs in a particular social discourse must be an "active" one, upon which the speaker counts in order to tell the story. It is difficult to discern the nature of this situation, however, because, to use Bakhtin's formulation, a speaker's "orientation toward the listener is an orientation toward a specific conceptual horizon, toward the specific world of the listener; it introduces totally new elements into his discourse; it is in this way, after all, that various different points of view, conceptual horizons, systems for providing expressive accents, various social 'languages' come to interact with one another." 15 This means that the type of discourse produced is not to be considered unified or untainted by the exterior world because "all words have the 'taste' of a profession, a genre, a tendency, a party, a particular work, a particular person, a generation, an age group, the day and hour. Each word tastes of the context and contexts in which it has lived its socially charged life; all words and forms are populated by intentions. Contextual overtones (generic, tendentious, individualistic) are inevitable in the word." 16 These contexts are constantly in evolution, just as the relationship between the speaker and the language he or she produces "is always found in a state of movement and oscillation that is more or less alive," ${ }^{17}$ but Angenot 
provides some hope that this relationship is nevertheless regulated by rules which, even if fluid and variable across genres, are nevertheless discoverable. The problem, for Angenot, is "to try to connect the literary, scientific, philosophical, political fields, and so forth, and without neglecting stakes, constraints and traditions of these individual fields to extrapolate transdiscursive rules, discover vectors of exchange, and set up a global topology of the prevailing sayable, accounting therefore for using 'Social Discourse' in the singular, and not social discourses as a simple coexistence and juxtaposition of genres, disciplines, and local cognitive strategies." 18

The difference between Angenot and Bakhtin on this point is in where they choose to place the emphasis of their work: for Angenot the "sayable" is tied to the conditions under which the speaking subject produces his or her utterance; for Bakhtin that same word however constrained is nevertheless the product of living, speaking individuals who are situated, in very specific ways, in space and time, and is in itself a "living" entity that goes out into the "environment" and is subjected to it even as it acts upon it: "The living utterance, having taken meaning and shape at a particular historical moment in a socially specific environment, cannot fail to brush up against thousands of living dialogic threads woven by socio-ideological consciousness around the given object of an utterance, it cannot fail to become an active participant in social dialogue. After all, the utterance arises out of this dialogue as a continuation of it and as a rejoinder to it - it does not approach the object from the sidelines." 19 The idea that dialogue itself is an organic entity, and that the space in which dialogue occurs is a living space, is crucial to Bakhtin, because "in any actual dialogue the rejoinder also leads such a double life: it is structured and conceptualized in the context of the dialogue as a whole, which consists of its own utterances .... and of alien utterances (those of the partner). One cannot excise the rejoinder from this combined context made up of one's own words and the words of another without losing its sense and tone. It is an organic part of a heteroglot unity." 20 This approach is a sign of Bakhtin's time, and its passing is marked by a less vitalistic, more historically materialist, but certainly carnivalesque, Marc Angenot.

\section{Science of Language}

Despite his more material approach, this idea of "living discourses" does bring us to a crucial point of concurrence between Angenot, Bakhtin, and Bourdieu concerning the possibility of applying a rigorous, scientific methodology to the realm of discourse; for all three, for related but somewhat different reasons, all dialogue is simply too infused with ideology, atmosphere, intentions, and situated perceptions 
to be usefully assessed through systematic, disconnected, methodological, and consistent forms of "discourse analysis" in the sense described by linguists like Zellig Harris or the plethora of semioticians and structuralists who tried to hone Saussure and Bloomfield-inspired ideas. This is where Angenot's work is closest to Bourdieu's, for whom the complexity of an utterance relates to conditions of production and reception, such that a discourse can only exist "so long as it is not simply grammatically correct but also, and above all, socially acceptable, i.e., heard, believed, and therefore effective within a given state of relations of production and circulation[;] it follows that the scientific analysis of discourse must take into account the laws of price formation which characterize the market concerned or, in other words, the laws defining the social conditions of acceptability (which include the specifically linguistic laws of grammaticality)." ${ }^{21}$ Although a comment upon the limitations of phonological, structural, or semiotic approaches to language studies, this is also a contribution to reception theory since, as Bourdieu suggests, "the conditions of reception envisaged are part of the conditions of production, and anticipation of the sanctions of the market helps to determine the production of the discourse." 22

Bakhtin is even more adamant on this point, because for him, if we detach ourselves completely from the "living impulse" of discourse, "all we have left is the naked corpse of the word, from which we can learn nothing at all about the social situation or the fate of a given word in life." In his most powerful condemnation of such false hopes, instilled by structuralist, formalist, or other science-inspired methods of discourse analysis, Bakhtin writes that "to study the word as such, ignoring the impulse that reaches out beyond it, is just as senseless as to study psychological experience outside the context of that real life toward which it was directed and by which it is determined." 23 This is why we need some sense of the "whole," of the organic, living space previously described. There could never be a point to bringing a rigorous methodology from the "hard sciences" to discourse analysis because "the entire methodological apparatus of the mathematical and natural sciences is directed toward mastery over mute objects, brute things, that do not reveal themselves in words, that do not comment on themselves. Acquiring knowledge here is not connected with receiving and interpreting words or signs from the object under consideration." 24 This critique runs both ways, because, as Bourdieu points out, "linguistic competence is not a simple technical capacity but a statutory capacity with which the technical capacity is generally paired, if only because it imposes the acquisition of the latter through the effect of statutory attribution, as opposed to the commonly held belief that regards technical capacity as the basis for statutory capacity." 25

Angenot's formulation of this in his description of social discourse 
has him admitting that "computerized discourse analysis based on a selection of discrete lexicological or morphological units certainly gives a stronger sense of rigor and verifiability." Unfortunately, or perhaps fortunately, such work "only leads to the discovery of tautologically obvious rephrasings." 26 His own approach, deemed "holistic," is more "risky" and "hazardous" because "you have to interpret, to relate seemingly heterogeneous phenomena, to determine what you will deem meaningful and to what degree it is so. You do that at your own risk and you cannot expect to cover your choices and proceedings with any all-inclusive insurance of scientificity." $27 \mathrm{He}$ had challenged such attempts at analytical rigor practiced on cultural production in his polemical text entitled Critique de la raison sémiotique: fragment avec pin up, published in 1985 and translated into English in 1994, with an introductory essay by Marie-Christine Leps. ${ }^{28}$ This text begins with the comment that Bakhtin and Volosinov's Marxism and the Philosophy of Language ${ }^{29}$ had already "criticized and radically questioned" Saussure's epistemological framework in the I920s, and that had this text been translated into French earlier one "might hope" that semioticians would have questioned "their fetishism and their exclusions" earlier on. It came too late, though, and "the present intellectual atmosphere, on the contrary, lets them feel at home amidst their self-satisfaction and eclecticism." ${ }^{30}$ It's true that this "present" intellectual atmosphere, so dominant in the I960s and '70s especially, was particularly salient for Angenot because of the power that structuralism and semiotics came to yield in Québec. (Even today one receives a Doctorate of Semiology from University of Québec in lieu of a Ph.D.) It's easy to forget just how powerful a hold structuralism, semiotics, and narratology had over literary studies, particularly in francophone countries like France, Switzerland, and Belgium:

Thirty years later, when the West European structuralist movement transformed the pseudo-Saussure of the Course in General Linguistics into a dogma for the arts and social sciences, Bakhtin's and Volosinov's text would have been timely, but it was not to be translated into French until I977. Some of the objections set out by Bakhtin had by then been expressed independently by other researchers (H. Lefebvre, Pierre Bourdieu). By this time, however, linguistics and even other semiologies had already permanently established themselves in an intellectual area from which history and ideology had been banished. ${ }^{31}$

Bakhtin recalled history and ideology to formalists of his era; Angenot brings to ours the scandal of history.

\section{Grand Narratives}

I first worked with Marc Angenot in I987 as a graduate student in the Comparative Literature Program, when I followed his course and was 
hired as a researcher to amass information relating to the massive text on $1889,,^{32}$ to which both Fredric Jameson and Michel Pierssens refer in their respective articles. That same year, I started a working papers series for the McGill Comparative Literature Program that Angenot suggested we call Discours social/Social Discourse, and which contained in its first issue an English language version of the research project describing social discourse theory that appears in this volume as "Social Discourse Analysis: Outlines of a Research Project." What started as local working papers in comparative literature turned into a quarterly journal, and led to a ten year odyssey of work on a range of subjects, many of which eventually related to Angenot's approach to literature, history, and language studies. The decisive shift in this direction occurred subsequent to McGill's (disastrous) decision to close its Comparative Literature Program, despite having within its ranks some of the most productive humanities scholars in the country, notably Angenot, Marike Finlay, Darko Suvin, and George Szanto, as well as direct links to the Comparative Literature Department at the Université de Montréal, which housed, among others, Wlad Godzich, Antonio Gómez-Moriana, Wladimir Krysinski, Walter Moser, Michel Pierssens (in French), Pierre Popovic, and the young Bill Readings. The Université du Québec was the venue for a range of work and conferences, and had within its ranks other crucial interlocutors, notably Pierre Ouellet and Régine Robin.

The crucial intellectual engagements during the period of Comparative Literature were, in particular, between Angenot, Suvin, and Szanto, who shared political ideals arrived at from very different places. Darko Suvin, as is evident from his contribution to this volume, is sympathetic to Marxist-Leninism, and was certainly drawn to what had bonded his world (Yugoslavia) together; when that country imploded, he continued or perhaps even reinvigorated his sense that Marxism could have been successful in certain worlds had Lenin's works been read carefully. Angenot's views of Marxism, and utopianism in a broader sense, are of course the subject of many of his books, and as is obvious from the interview that follows this introduction, he is interested in things that occur prior to the answers provided by Marx or any of his followers. This is the European engaged intellectual asking about engaged intellectualism, which Suvin does as well when he thinks about the role of Angenot's approach to the world. In his contribution to this volume, Suvin demands something that Angenot doesn't wish to provide, i.e., a template for a good society, or even a way in which discourse analysis could offer such a thing to someone like himself, who considers it not only desirable but imperative. For Suvin, the answer to the question of the good society cannot be found in discourse analysis or social discourse. Indeed, "the 
mainstream of discourse theory is a production of contained, nonrevolutionary time, a thinking of stasis manifest in its predilection for synchronic coupes." 33 It was insufficient to the task of Northern capitalism and oppression of this "post-Fordist" period: "radical alternatives of any kind cannot be really thought of in classical discourse theory" for the simple reason that "the dynamic diachrony, ... how \& why discursive formations evolve \& change, was never visible in discourse theory. It was, indeed, its non-dit. This seems to me both politically \& intellectually stultifying." 34 However, says Suvin, Angenot overcomes these shortcomings in such essays as "Présupposé, topos, idéologème," which approaches the critical issue of the "tacit implications, . . the linguistic \& institutionalized presuppositions of discourse." 35

George Szanto brought to the equation a powerful interest in narrative, as well as a series of strategies inspired by the Frankfurt School and Fredric Jameson (his thesis director) that tied his work on fiction and aesthetics to a Marxist approach to culture. Szanto recalled that:

It is sometimes the slim volumes rather than the major works of a fine mind that fall on someone else's fertile ground, and so it was with my introduction to Marc Angenot. Soon after we (with Darko Suvin) started the McGill Comparative Literature Program together, I read his book on the natural superiority of women, Les Champions des femmes. ${ }^{36}$ The historical research, as well as the thesis, stayed with me for many years thereafter, and I always wanted to do something with it. Though it was not, to my consciousness, the source of a fictional character I recently created - the Mexican noblewoman, Maria Victoria, Condesa of Michoácuaro ${ }^{37}$ - certainly Marc's argument for such a swathe of thought within eighteenth century rationalism provided the Condesa with whatever historical legitimacy she possesses. ${ }^{38}$

Szanto, always (and still) a fiction-writer in addition to being a literary and cultural critic, practiced and wrote about the art of telling stories, and he, along with Suvin, a poet, and Finlay, a short story writer, held fast to the idea of fiction as a privileged realm which Angenot, as is evident in "What Can Literature Do?", challenged in his efforts to contextualize all utterances within a broad compendium of social discourse(s). This is one of the two productive differences between Suvin and Angenot that fueled their 3I years of friendship and discussions, and to which Suvin refers in his descriptions of "a discursively reasoned series of critical meditations about two of the major divergences Marc Angenot \& I have noticed for some time, i.e., about discourse theory \& teaching of belles lettres."39 Suvin's gripe with Angenot, which served both thinkers in the way it sharpened respective approaches, is with the latter's approach to literature: "This is the obverse-\&/or presupposition — of discourse theory: for if one wishes to deal with literature (in the widest, which was also the original, sense of all that is written in letters) \& yet not with literature in the postromantically restricted sense of belles lettres by geniuses, how can one 
discuss \& teach it in the present academy? As (part of) something else: cultural studies, or discourse analysis." ${ }^{40}$ This is highly problematic for Suvin, and Angenot, despite his great erudition and incredible knowledge of fiction in a range of languages, seems to fall into it, even though "Marc would certainly not wish to get rid of the consumption or indeed production of fiction. He just wishes to help it by ridding it of academic interpretation." 41

In I994 I was awarded a post-doctoral fellowship to work at the Université libre de Bruxelles (ULB) with an old friend of Angenot's, Michel Meyer, whose work on questioning, problematology, argumentation, and the passions have made him one of the leading francophone philosophers of this century. Angenot, who was researching in France the summer before my tenure was to begin at the ULB, offered to drive with me from Paris to Brussels to introduce me to Meyer and to the institution to which he had been affiliated for so long. What struck me in the days we spent together traveling to Brussels, and then visiting the university and the city, was Angenot's endless curiosity and his (concomitant) encyclopedic knowledge. As we drove down the highway Angenot would analyze or make historically-based observations about the license plates of passing cars, the shapes of roadside signs, the architecture of buildings we passed, and the politics of each region we traversed. Whenever we stopped to eat somewhere, Angenot bestowed immeasurable pleasure upon waiters and waitresses by making reference to the most minute local custom, by ordering without having to even consult the menu the most typical of regional culinary specialties, and by knowing without asking all the names of the most revered local beverages. Furthermore, Angenot sought out the workers' hangouts, the seedy bars, and the most down-to-earth settings wherever he went. The theory of social discourse, which demands that we must come to know all of the discourses and experiences of a given society without hierarchical discrimination, since they come to form a discursive whole which in turn establishes the discourse rules for each specific genre, seemed to grow right out of his approach and experience of the world. He himself was and remains a living representative of how the theory could come to be applied in everyday life.

\section{ICDAST vs. French Theory}

To continue some of the work of the Comparative Literature Program post-McGill, Angenot decided, along with Régine Robin and Antonio Gómez-Moriana, to form the Inter-University Centre for Discourse Analysis and Sociocriticism of Texts (ICDAST), which would link work undertaken in that broad vein in Québec universities, notably McGill, Université de Montréal, and the University of 
Québec. The rift in that group from the very outset concerned the role of literature, although debates extended outward with the introduction of Popovic's assessment of sociocriticism of poetry, the growing influence of the psychoanalysts in the group, the implications of a fallen Soviet Union to a group which had within its ranks so many thinkers with ties to the Eastern bloc, notably Wlad Godzich, Wladimir Krysinski, Régine Robin, and Darko Suvin, and, from an institutional standpoint, the nature of an inter-university research group that should have sailed the world's seas like a ship of academic fools but instead was tied to the dreary University of Québec offices in buildings consecrated to strip clubs and retail stores.

The question from an American standpoint could be: why did this group, so uniquely situated to assess first-hand the implications of "French theory" for an English audience, remain more or less mute to its provocations? This is not to say that the pantheon of French philosophers and theorists didn't find their way to the halls of Québec institutions, quite the contrary. As Jürgen Link notes in his introduction to Edmond Cros's book Sociocriticism, 42 Montréal has served as a "plaque tournante" for French theory, the place in which theorists like Baudrillard and Derrida, not to mention lesser-known (to an American audience) but crucially important figures like Jacques Dubois, Claude Duchet, and Henri Mitterand, found their way to America. But as we have seen, beyond Bourdieu and Foucault, and for very specific reasons, the pomo French theory was of little concern to Marc Angenot and even to the many theorists with whom he worked, within and beyond the institutes and academic settings. The reasons for this relate to the very historical and philological nature of his work, reflected in some of the hypotheses he sets out in a work called “"One does not write good literature with good sentiments': French Theory, Modernist Writing, American Militancy."43 Although it is too lengthy to cover here in its entirety, and probably too provocative without clear context to be included in this collection, this piece is nevertheless worth mentioning. On deconstruction, and the many acolytes associated thereto, Angenot devotes his first hypothesis, which "relates to the function which this common recourse to certain skeptical and relativist theories from France fulfills in the North-American academic world. I can find only one ultimate justification for the hegemony of deconstructionism in America, and only one mission which has been well fulfilled: to cut off literary studies from historical, social and philological sciences which, in the sixties, threatened to absorb them." 4 This is an appropriately institutional analysis, consistent with the types of assessments put forth in Bourdieu's sometimes raucously funny Homo Academicus. Consistent with this sociological approach, Angenot then goes on to propose after citing figures that show the excessive production of theoretical texts, in book and article form, that 
the requirements of academic careers in an overcrowded and saturated field, which is losing prestige, have generated an increasing number of publications by a growing number of professors who must deal with a university press system which is on the verge of asphyxia and collapse. A sociologist will tell you that this forced inflation of books that no one reads (because no one could possibly read them), requires strategies under pressure, which one will try to legitimate in order to create an academic capital and to occupy a market, but which are anomical or heteronomical, which create a rupture with the field's traditional logic: allegiance to an ideological group, to a militant movement, if possible one that is popular among the young. You can also try overstatement borrowed from the media, historically foreign to the academic world, on the spot and fashionable analyses of single issues, of simplistic themes which are popular and may arouse an interest outside academic circles (in The Journal of Scholarly Publishing in Toronto, William C. Dowling analyzes some amazing cases of what he terms "Scholarly Publishing in the Age of Oprah"), but also, paradoxically, a withdrawal into orthodox theories and a striving to gain and retain the loyalties of an orthodox student clientele which may renew the need for a certain rehashed ideological product. ${ }^{45}$

Hearkening back to many critiques of postmodern work, by the likes of Noam Chomsky and Christopher Norris, and fueled by such scandals as the revelations about Paul DeMan, or the Sokal hoax, Angenot finds that "post-modernist pyrrhonism, used so ostentatiously, has worked and in my opinion is still functioning in North America as a defense mechanism and as self-promotion, which paradoxically legitimized an academic field, and which is used as a weapon by a generation desperate to be recognized, faced with extreme competition between its members, all looking for a common school and for a method which combines the double advantage of apparent radicalism and facility." 46 This idea, noted in regard to the work of (among others) Judith Butler, is bolstered through philosophical analysis and argued by demonstrating the empty rhetorical strategies so often used to create entire systems of self-reference:

What strikes me is that this work constantly quotes Lacan, Foucault, Irigaray and others without any critical analysis or demonstration, using terms like "Foucault points out that ...," "Simone de Beauvoir suggests that ...," "Irigaray would maintain ..." as if in the midst of a radical doubt on the existence of the empirical world and on the power of human reasoning, one could quote authors like revelations from the Gospel or the Apocalypse! Foucault points out, Lacan suggests and Irigaray claims many things, which are often incompatible. The constant recurrence of these verbs suggests that their assertions, taken out of context and of argumentation, can function as indubitable revelations in a labile and deconstructed world. ${ }^{47}$

All of this adds up to a "nihilism" in the world of Anglo-American criticism, in which authors seek to legitimize themselves "in the face of a loss of credibility and influence." 48 Again, consistent with Bourdieu, Angenot finds an academic world that has effected an "autistic professionalization" which, when it combines with various social and 
political forms of activism, including various forms of identity activism, "constitutes a new, obvious intellectual paradox." 49

Despite the alternative it offered to current postmodern debates and the breadth and depth of its productions, ICDAST (and the journal Social Discourse) have now become relics that need to be dusted off, despite the fact that their contributions still apply to an array of debates and concerns. As the product of contemporary desktop publishing technology and a hefty photocopy budget, Social Discourse eventually produced monographs, working papers, and limited-circulation books, and still churns out occasional working papers. Angenot, with his recently-reinvigorated publishing output and a 200I James McGill Professorship of French Language and Literature, beckons like a revitalization for humanities and social sciences alike.

\section{The Passions of the Café concerts and the Savon du Congo}

Angenot's passions are also, or perhaps primarily, bodily; his work and his life herein merge, and everything becomes "larger than life," from his corpus of 25 or so books and hundreds of articles to his remarkably vibrant presence. He is a man who is "turned on" by the omnipresent oddities, confused lusts, effervescent banalities, and sweet stupidity of life lived in an endlessly-degenerating and constantly revitalizing carnivalesque body. He is without doubt the most curious person I've ever known, a Benjaminian collector of index cards upon which he carves with magnificent handwriting the long-forgotten words of everyone who ever spoke, whether or not they were recognized as having anything particularly interesting to say. When I first met him he spoke English shyly and seldom; today he speaks with the oratorical flair of an English barrister. When I introduced him to the computer in the late I980 he was still writing each word of his growing oeuvre on the paper one might have used to write letters to a long-lost lover; today he is a cottage industry master of his own website, which he fills with the wise words and slipshod "hits" that make up cyberspace-informed linguistic production. Anyone who knows him wonders if there isn't a secret cache of poetry hidden away somewhere, even though, as he is apt to remind you, it is not by loving or having sex that one gains the aptitude or the desire to become a sexologist.

To find the creativity in Angenot's work one must simply engage the munificent prose and the tantalizing ideas with which he fills his, and our, world. It's not always skeptical, or "sceptique," as he himself defines his work; it is also ludic and funny in the way that Chomsky's work is, and it is similarly performed with tremendous gusto and charisma. There was a phase, when I was still a graduate student, when 
Marc would invariably break into song during his academic presentations. He was at the time involved in the distinctly anti-McLuhan project of studying the café-concert in order to ask whether we can understand a society by figuring out what it sings. In I992, as I submitted to him and George Szanto my Ph.D. dissertation, he also received from Éditions des Cendres advance copies of his wonderful text, L'oeuvre poétique du Savon du Congo, ${ }^{50}$ a parody on the scientific research projects of the nineteenth century, applied in this case to the "woefully neglected" poetic advertisements for perfumed soaps produced by the Savonnerie Vaissier Frères in Roubaix. This collection of poetic works written in the service of advertising is a tonguein-cheek but sweetly serious rumination on a varied corpus of work by a host of writers, including perhaps the likes of Verlaine and Mallarmé, who were all brought together by M. Victor Vaissier, a devoted amateur of poetic publicity. Be that as it may, we'd all benefit from the refreshing powers of such a product, and in reading the descriptions thereof we learn, in addition to so many other things, "curious and interesting" facts about Émile Zola's methods, as described in one of the many wonderful poetic examples cited and assessed in this remarkable text, which recalls examples of the poetry written to promote this brand of soap:

Quand Zola sous son front sent bouillir son cerveau,

Quand sa phrase en longueur s'allonge en ciselure,

Quand il sent des moiteurs courir sur sa figure,

Il rafraîchit ses sens, les fièvres de sa peau

En se plongeant tout net dans un bain de Congo. ${ }^{51}$

Overall, says Angenot, in a conclusion that could apply to any number of discourses he has found in his search for the uttered social world, these little poems are an inexhaustible corpus for the curious reader: "Démocratiquement collective, subversivement intertextuelle, traditionnelle et moderniste, lyrique et prophylactique, la poésie du Savon du Congo mérite de figurer en bonne place dans le panthéon des lettres françaises, dût en pâlir l'étoile des Laforgue, Mallarmé, Moréas, Henri de Régnier et autres Verhaeren." 52

These few words recall in a flash a massive project that underwrites the Angenot approach, a coherent and rather daunting task to which he devotes his efforts, of which this special issue can but offer a tiny glimpse. To help guide the reader, I've begun with a recent interview with Angenot that ranges freely across vistas of work in which he has been involved over the last few years, and an article, published for the first time in English, which offers a sense of the social discourse project but also productively challenges some of the assumptions that underwrite contemporary studies in a range of disciplines as broad and 
restricted as the academy itself. To further assist us in the encyclopedic voyage through Angenot's work, we have as well enjoined the very best of guides. Fredric Jameson's article on literary history is a long reading of the seminal Angenot book 1889, which, in Jameson's words, is "a classic if anything ever was." Darko Suvin offers his sweeping and critical assessment of Angenot's overall approach to discourse and fiction in a challenging and ludic tribute to a longtime friend and collaborator. Marie-Christine Leps, who wrote a thesis under Angenot and has gone on to evaluate his insights from a range of perspectives, juxtaposes Angenot's work with Bakhtin's and Foucault's. Michel Pierssens, another of Montréal's erudite European scholars, provides a wise reflection upon the accomplishments and originality of the work Angenot has crafted through these last decades. And finally, I offer, in addition to these few words, my own heartfelt hope that this collection will inspire readers engrossed in these questions to take full advantage of the books and articles by and about a formidable but beckoning Marc Angenot.

\section{Notes}

I Marc Angenot, “'One does not write good literature with good sentiments': French Theory, Modernist Writing, American Militancy," a talk given at the University of Western Ontario, Canada, 200o. For a copy of this work see <http://groups.msn.com/pagedemarcangenot/ discourssocial.msnw>.

2 Darko Suvin, "Besinnung and What May the Century Amount To: On or About or Because of Marc Angenot as Goad and Stimulus," Yale Journal of Criticism I7.2 (2004): 300.

3 Marc Angenot, Le Roman populaire: recherches en paralittérature (Montréal: Presses de l'Université du Québec, 1975).

4 Marc Angenot, La Parole pamphlétaire: contribution à la typologie des discours modernes (Paris: Payot, I982).

5 Marc Angenot, "Social Discourse Analysis: Outlines of a Research Project," Yale Journal of Criticism I7.2 (2004): I99. On his own sense of intellectual debts, Angenot writes: "The francophone thinkers who have influenced me at different times in my career (I will mention only those who are or were alive when I began to think about their work), are Chaim Perelman, Lucien Goldmann, Joseph Gabel, Jean-Pierre Faye, Luis Prieto, Zeev Sternhell, Pierre Bourdieu .... It is not surprising that not all of them are well-known on this side of the Atlantic. The work of intellectual perlaboration does not depend on notoriety and immediate relevance. Of course, I must add Roland Barthes to this short list, given that his posthumous crash requires that one recognize his stimulating role for scholars of my generation. The only name which also belongs to the canonical American list of French Theorists is that of Michel Foucault, which I will talk about, but only to show that influence does not necessarily entail adherence. Contact with the work of Foucault has taught me a lot, but almost always a contrario, as I admired his conjectures and progress but, in the end, I rejected most of his premises, approaches and conclusions. Furthermore, in thinking about Foucault, I confronted his ideas with those of Koyré, Bachelard, Kantorowitz, Popper, Kuhn and other less brilliantly nihilistic epistemologists, and compared his history of I9th-century sexuality with that of Peter Gay for instance, who contradicts him in all regards. This may sound like rather deceitful praise, but it is sincere, and this is the way it often happens in the evolution and spread of ideas. Saying this at the outset in no way underestimates Michel Foucault's innovative talent—nor his obvious faults. You might object that revealing my little francophone pantheon does not mean anything. For one thing, like 
many others, I was also heavily influenced by English-speaking historians like Eric Hobsbawm, Norman Cohn, and by sociologists like Irving Goffmann, linguists like Zellig Harris, and various 'logical empiricists' and discourse analysts, but also by German-speaking thinkers, including Georg Lukàcs and Frankfurt thinkers Max Horkheimer, Walter Benjamin and Theodor W. Adorno, and by the great Slavic philologists and critics, from Roman Jakobson to Mikhail Bakhtin and Jan Mukarovskì." (Angenot, "One does not write ....”)

6 Mikhail Bakhtin, "Discourse in the Novel," in The Dialogic Imagination: Four Essays by M.M. Bakhtin, ed. Michael Holquist, trans. Caryl Emerson and Michael Holquist (Austin: Texas University Press, I98I), 27I.

7 Angenot, "Social Discourse Analysis," 204.

8 Bakhtin, 262-3.

9 Ibid., 276.

Io Ibid., 28I.

II Angenot, "Social Discourse Analysis," 207.

I2 Pierre Bourdieu, Language and Symbolic Power, trans. John B. Thompson (Cambridge: Harvard University Press, I993), 66.

I3 Ibid., 67.

I4 Angenot, "Social Discourse Analysis," 200.

I5 Bakhtin, 282.

I6 Ibid., 293.

I7 Ibid.

I8 Angenot, "Social Discourse Analysis," 200.

I9 Bakhtin, 277.

20 Ibid., 284.

2I Bourdieu, 76

22 Ibid., 76-7.

23 Bakhtin, 292.

24 Ibid., 35 I.

25 Bourdieu, 69.

26 Angenot, "Social Discourse Analysis," 202.

27 Ibid.

28 Marc Angenot, Critique of Semiotic Reason, intro. Marie-Christine Leps, ed. Raymond Morris, trans. F. Collins (New York, Toronto: Legas, 1994).

29 V. N. Volosinov, Marxism and the Philosophy of Language, trans. Ladislav Matejka and I. R. Titunik (Cambridge: Harvard University Press, I986).

30 Angenot, Critique, 2.

3I Ibid.

32 Marc Angenot, Mil huit cent quatre-vingt-neuf: un état du discours social (Montréal/Longueuil: Éditions du Préambule, 1989).

33 Suvin, 296.

34 Ibid., 297.

35 Ibid.

36 Marc Angenot, Les Champions des femmes. Examen du discours sur la supériorité des femmes, 1400-1800 (Montréal: Presses de l’Université du Québec, 1977).

37 George Szanto, The Condesa of M. (Toronto: Cormorant/Stoddart, 200I).

38 Personal correspondence with author, 2004.

39 Suvin, 290.

40 Ibid., 300.

4I Ibid.

42 This text was originally published by CERS Montpellier in I983 as Théorie et pratique sociocritiques, and was translated as Sociocriticism, trans. J. Schwartz (Minneapolis: University of Minnesota Press, I988), I.

43 See note I.

44 Angenot, "One does not write ...."

45 Ibid.

46 Ibid. 
47 Ibid.

48 Ibid.

49 Ibid.

50 Marc Angenot, L'Oeuvre poétique du Savon du Congo (Paris: Éditions des Cendres, I992).

5I Ibid. 5I. The poem appeared in Le Petit Parisien, 4 October 1889.

52 Ibid., 74. 